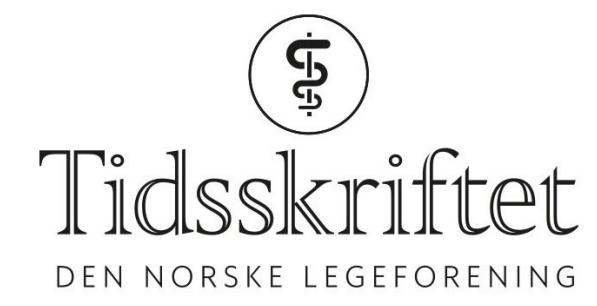

\title{
Rettelse: Lungeembolisme hos en pasient med Klinefelters syndrom
}

RETTELSE

MAGNUS LEIDLAND

BRITT UNDHEIM

ANAGHA P. PARKAR

LASSE MELVAR GIIL

Tidsskr Nor Legeforen 2021; 141: 16o-1.

I Tidsskriftet nr. 2/2021, s. 16o og 161 skal navnet på tredjeforfatter være Anagha P. Parkar. Vi beklager feilen, den er rettet på nett.

Publisert: 4. mars 2021. Tidsskr Nor Legeforen. DOI: 10.4045/tidsskr.21.0146 (C) Tidsskrift for Den norske legeforening 2020. Lastet ned fra tidsskriftet.no 